\title{
Profile Characteristics, Constraints and Suggestions of Head Reach and Tail End Paddy Growers in Adopting Climate Resilient Technologies
}

\author{
K. V. Manjunath*, K. Shivaramu, Kalla Ashok and Dadimi Anilkumar Reddy \\ U Department of Agricultural Extension, University of Agricultural Sciences (GKVK), \\ Bengaluru - 560 065, Karnataka, India \\ *Corresponding author
}

\begin{abstract}
A B S T R A C T
The present study was conducted during 2017-18 in Mandya district of Karnataka. Two villages each in Tail end area and Head reach area of Krishna Raja Sagar (KRS) Dam were randomly selected. In each selected village 25 paddy growers were randomly selected. Thus 100 farmers (50 each in head reach and tail end area) constituted the sample for study. The findings reveal that majority of paddy growers interviewed belonged to middle age, primary school education, high farming experience, medium level of cosmopoliteness, risk orientation, social participation, innovative proneness and scientific orientation in both Head reach and Tail end regions, whereas Tail end respondents were having high extension participation and extension contact in comparison to Head reach farmers. Lack of sufficient knowledge and guidance about the climate resilient technologies, limited extension activities about climate resilient technologies and Non availability of labour to adopt climate resilient technologies are the major constraints of Head reach growers Whereas untimely release and improper scheduling of water in the canals, uneven and untimely rainfall and non-availability of labour are severe constraints reported by Tail end growers. Major suggestions offered are creating awareness to the farmers on scientific water management, involvement of local farmers in decision making in releasing water to the canals and Ensuring timely availability of inputs by Head reach growers, whereas Involvement of local farmers in decision making in releasing water to the canals, creating awareness to the farmers on scientific water management and increasing subsidies on micro irrigation structures by Tail end growers.
\end{abstract}

\section{Keywords}

Climate resilient, Constraints, Head reach, Paddy growers, Tail end, Suggestions

\section{Article Info}

Accepted:

17 August 2020

Available Online:

10 September 2020

\section{Introduction}

Indian agriculture is highly dependent on monsoon rains, and a close link exists between climate and water resources. The effects of change in climate are global, but countries like India are more vulnerable in view of the high population depending on agriculture. In India, significant negative impact has been implied with medium-term (2010-2039) climate change, predicted to reduce yields by 4.5-9 per cent, depending on the magnitude and distribution of warming. Since agriculture makes up roughly $16 \%$ of India's GDP, a 4.5-9 per cent negative impact on production implies a cost of climate change to be roughly up to 1.5 per cent of GDP per year (Venkateswarlu et al., 2013). 
Climate change is a change in the statistical dispensation of weather patterns, when that change lasts for an external period of time. This may refer to alteration in average weather conditions or in the variations of weather around long - term average conditions.

The productivity of most cereals would decrease due to the increase in temperature and $\mathrm{CO} 2$ and the decrease in water availability. There will be a projected loss of $10-40 \%$ in crop production by 2100 if no adaptation measures are taken. A degree Celsius increase in temperature may reduce yields of major food crops by $3-7 \%$ (IPCC, 2007). Rice production is slated to decrease by almost a ton/hectare if the temperature goes up by $2^{\circ} \mathrm{C}$. The waterlogged and warm soils of paddy make production system a large emitter of methane.

Rice production is and will be affected by changes in climatic factors like irregular rainfall, long dry spells during wet season (damaging young plants), drought and floods all having an effect on yields. This has also caused outbreaks of pests and diseases, with large losses of crops and harvested products. Number of methods and practices are being adopted to address climate change challenges by altering cropping patterns, planting dates and farm management techniques. Embankments have been built to save paddy fields from floods and drought and submergence tolerant varieties of rice are being developed and distributed by government and private organisations. The development of advanced modelling techniques, mapping the effect of climate change on rice growing regions and providing crop insurance are other examples of managing risks and reducing vulnerability. With this background the present study was undertaken with the following specific objectives include to know the profile characteristics of Head reach and Tail end paddy growers of Mandya district of Karnataka and also to document the constraints and suggestions of Head reach and Tail end paddy growers in adopting climate resilient technologies in paddy.

\section{Materials and Methods}

The study was conducted in Mandya district of Karnataka state during 2017-18 using expost facto research design. Two villages each in Tail end area and Head reach area of Krishna Raja Sagar (KRS) Dam were randomly selected. In each selected village 25 paddy growing farmers were randomly selected. Thus 100 farmers (50 each in head reach and tail end area) constituted the sample for the study. The selected respondents were personally interviewed using pre-tested interviewed schedule. The data was tabulated and analysed using appropriate suitable statistical measures.

\section{Results and Discussion}

Personal, socio-economic, psychological and communication characteristics of Head reach and Tail end paddy growers

In Head reach area nearly half (48\%) of the respondents belonged to middle age category followed by old age (38\%) and young age category $(14 \%)$. In tail end area slightly less than half $(44 \%)$ of the respondents belonged to middle age category followed by old age (36\%) and young age category $(20 \%)$.

In the head reach area, slightly more than one fourth of the respondents $(28 \%)$ had completed their primary education, equal per cent $(22 \%)$ of the respondents have completed their middle school and high school, followed by puc (14\%), graduation ( 8 $\%$ ) and only a meager per cent (6\%) of respondents were illiterates. With regard to 
the literacy level in the tail end area, almost one fourth of the respondents have completed their high school education (24\%), one fifth of the respondents $(20 \%)$ have completed their primary and puc education, followed by middle school (16\%), graduation and above (12\%) and only a small fraction of the respondents $(8 \%)$ were found to be illiterate.

In the head reach area majority of the respondents $(46 \%)$ were small farmers, followed by marginal farmers $(40 \%)$ and big farmers $(14 \%)$. In the tail end area slightly less than half of the respondents $(48 \%)$ were marginal farmers, followed by small farmers $(36 \%)$ and big farmers (16\%).

In the head reach area, slightly less than two fifth $(38 \%)$ of the respondents were belonged to high level income group (50\%), followed by 32 percent to medium level and 30 per cent to high level annual income. In the tail end area, great majority of the farmers were belonged to medium level income group (46 $\%)$, followed by low level (34 \%) and high levels $(20 \%)$ of annual income. In the head reach area great majority of the respondents were belonged to higher level of farming experience $(50 \%)$ followed by moderate level $(30 \%)$ and low level $(20 \%)$ of farming experience. In the tail end area also large proportion of the respondents were belonged to higher level of farming experience $(46 \%)$ followed by moderate level (42\%) and low level $(14 \%)$ of farming experience.

In the Head reach area also significant portion of the respondents $(66 \%)$ were belonged to nuclear family and the rest of the respondents (34 \%) to joint family. In the tail end area majority of the respondents $(72 \%)$ were belonged to nuclear family and the remaining respondents $(28 \%)$ to joint family.

In the head reach area, half of the respondents
(50\%) belonged to medium sized family followed by 28 per cent belonged to small family size and 22 per cent of the respondents belonged to bigger family size. In the tail end area, greater proportion $(58 \%)$ of the respondents belonged to medium sized family followed by 24 per cent belonged to small family size and 18 per cent of the respondents belonged to big family size.

In the head reach area, less than two fifth of the respondents $(38 \%)$ had medium level of cosmopoliteness, followed by low level (36 $\%)$ and high level (26\%) of cosmopoliteness. In the tail end area, slightly less than half of the respondents $(44 \%)$ had medium level of cosmopoliteness, followed by high level (32 $\%)$ and low level (24\%) of cosmopoliteness.

In the head reach area majority of the respondents had medium level (38\%) risk orientation followed by low (34\%) and high level $(28 \%)$ risk orientation. In the tail end area, slightly less than half $(42 \%)$ of the respondents had high risk orientation, followed by medium (32\%) and low level (26 $\%)$ risk orientation.

In the head reach area majority of the respondents (42\%) belonged to low extension contact category, followed by medium (34\%) and high level (24\%) extension contact category. In the tail end area, two fifth $(40 \%)$ of the respondents belonged to high extension contact category, followed by medium (36\%) and low level (24\%) extension contact category. In the head reach area, two fifth (40 $\%$ ) of the respondents belonged to medium level social participation, followed by high (32 \%) and low level (28\%) social participation. In the tail end area, 44 per cent of the respondents belonged to medium level social participation, followed by high (32\%) and low level $(24 \%)$ social participation (Table 1). 
Table.1 Personal, socio-economic, psychological and communication characteristics of Head reach and Tail end paddy growers $(n=100)$

\begin{tabular}{|c|c|c|c|c|c|c|c|c|}
\hline \multirow{2}{*}{$\begin{array}{l}\text { Sl } \\
\text { No. }\end{array}$} & \multirow[t]{2}{*}{ Characteristics } & \multirow[t]{2}{*}{ Category } & \multicolumn{2}{|c|}{ Head reach } & \multicolumn{2}{|c|}{ Tail end } & \multicolumn{2}{|c|}{ Total } \\
\hline & & & No. & $\%$ & No. & $\%$ & No. & $\%$ \\
\hline \multirow[t]{3}{*}{1} & \multirow[t]{3}{*}{ Age } & Young & 7 & 14.00 & 10 & 20.00 & 17 & 17.00 \\
\hline & & Middle & 24 & 48.00 & 22 & 44.00 & 46 & 42.00 \\
\hline & & Old & 19 & 38.00 & 18 & 36.00 & 37 & 37.00 \\
\hline \multirow[t]{6}{*}{2} & \multirow[t]{6}{*}{ Education } & Illiterate & 3 & 6.00 & 4 & 8.00 & 7 & 7.00 \\
\hline & & Primary & 14 & 28.00 & 10 & 20.00 & 24 & 24.00 \\
\hline & & Middle school & 11 & 22.00 & 8 & 16.00 & 19 & 19.00 \\
\hline & & High school & 11 & 22.00 & 12 & 24.00 & 23 & 23.00 \\
\hline & & PUC & 7 & 14.00 & 10 & 20.00 & 17 & 17.00 \\
\hline & & $\begin{array}{l}\text { Graduation } \\
\text { and above }\end{array}$ & 4 & 8.00 & 6 & 12.00 & 10 & 10.00 \\
\hline \multirow[t]{3}{*}{3} & \multirow[t]{3}{*}{ Land holding } & Marginal & 20 & 40.00 & 24 & 48.00 & 44 & 44.00 \\
\hline & & Small & 23 & 46.00 & 18 & 36.00 & 41 & 41.00 \\
\hline & & Big & 7 & 14.00 & 8 & 16.00 & 15 & 15.00 \\
\hline \multirow[t]{3}{*}{4} & \multirow[t]{3}{*}{ Annual income } & Low & 15 & 30.00 & 17 & 34.00 & 32 & 32.00 \\
\hline & & Medium & 16 & 32.00 & 23 & 46.00 & 39 & 39.00 \\
\hline & & High & 19 & 38.00 & 10 & 20.00 & 29 & 29.00 \\
\hline \multirow[t]{3}{*}{5} & \multirow[t]{3}{*}{ Farming experience } & Less & 10 & 20.00 & 7 & 14.00 & 17 & 17.00 \\
\hline & & Moderate & 15 & 30.00 & 20 & 42.00 & 35 & 35.00 \\
\hline & & High & 25 & 50.00 & 23 & 46.00 & 48 & 48.00 \\
\hline \multirow[t]{2}{*}{6} & \multirow[t]{2}{*}{ Family type } & Nuclear & 33 & 66.00 & 36 & 72.00 & 69 & 69.00 \\
\hline & & Joint & 17 & 34.00 & 14 & 28.00 & 31 & 31.00 \\
\hline \multirow[t]{3}{*}{7} & Family size & Small & 14 & 28.00 & 12 & 24.00 & 26 & 14.00 \\
\hline & & Medium & 25 & 50.00 & 29 & 58.00 & 54 & 54.00 \\
\hline & & Big & 11 & 22.00 & 9 & 18.00 & 20 & 20.00 \\
\hline 8 & Cosmopoliteness & Low & 18 & 36.00 & 12 & 24.00 & 30 & 30.00 \\
\hline & & Medium & 19 & 38.00 & 22 & 44.00 & 41 & 41.00 \\
\hline & & High & 13 & 26.00 & 16 & 32.00 & 29 & 29.00 \\
\hline 9 & Risk orientation & Low & 17 & 34.00 & 13 & 26.00 & 30 & 30.00 \\
\hline & & Medium & 19 & 38.00 & 16 & 32.00 & 35 & 35.00 \\
\hline & & High & 14 & 28.00 & 21 & 42.00 & 35 & 35.00 \\
\hline 10 & Extension contact & Low & 21 & 42.00 & 12 & 24.00 & 33 & 33.00 \\
\hline & & Medium & 17 & 34.00 & 20 & 40.00 & 37 & 37.00 \\
\hline & & High & 12 & 24.00 & 18 & 36.00 & 30 & 30.00 \\
\hline 11 & Social participation & Low & 14 & 28.00 & 12 & 24.00 & 26 & 26.00 \\
\hline & & Medium & 20 & 40.00 & 22 & 44.00 & 42 & 42.00 \\
\hline & & High & 16 & 32.00 & 16 & 32.00 & 32 & 32.00 \\
\hline 12 & Economic motivation & Low & 14 & 28.00 & 12 & 24.00 & 26 & 26.00 \\
\hline & & Medium & 17 & 34.00 & 21 & 42.00 & 38 & 37.00 \\
\hline & & High & 19 & 38.00 & 17 & 34.00 & 36 & 36.00 \\
\hline 13 & Innovative proneness & Low & 15 & 30.00 & 12 & 24.00 & 27 & 27.00 \\
\hline & & Medium & 21 & 42.00 & 16 & 32.00 & 37 & 37.00 \\
\hline & & High & 14 & 28.00 & 22 & 44.00 & 36 & 36.00 \\
\hline 14 & Mass media exposure & Low & 13 & 26.00 & 11 & 22.00 & 24 & 24.00 \\
\hline & & Medium & 20 & 40.00 & 21 & 42.00 & 41 & 41.00 \\
\hline & & High & 17 & 34.00 & 18 & 36.00 & 35 & 35.00 \\
\hline 15 & Scientific orientation & Low & 18 & 36.00 & 14 & 28.00 & 32 & 32.00 \\
\hline & & Medium & 19 & 38.00 & 16 & 32.00 & 35 & 35.00 \\
\hline & & High & 13 & 26.00 & 20 & 40.00 & 33 & 33.00 \\
\hline 16 & Extension & Low & 19 & 38.00 & 11 & 22.00 & 30 & 30.00 \\
\hline & participation & Medium & 17 & 34.00 & 17 & 34.00 & 34 & 34.00 \\
\hline & & High & 14 & 28.00 & 22 & 44.00 & 36 & 36.00 \\
\hline
\end{tabular}


Table. 2 Constraints in adoption of climate resilient agricultural technologies as perceived by Head reach and Tail end paddy growers $(n=100)$

\begin{tabular}{|c|c|c|c|c|}
\hline $\begin{array}{r}\text { Sl } \\
\text { No. }\end{array}$ & Constraints & Score & Mean score & Rank \\
\hline $\mathbf{A}$ & \multicolumn{4}{|l|}{ Head reach $(\mathrm{N}=50)$} \\
\hline 1 & $\begin{array}{l}\text { Lack of sufficient knowledge and guidance about } \\
\text { the climate resilient technologies }\end{array}$ & 133 & 2.66 & $\mathrm{I}$ \\
\hline 2 & $\begin{array}{l}\text { Limited extension activities about Climate } \\
\text { Resilient agricultural technologies }\end{array}$ & 127 & 2.54 & II \\
\hline 3 & $\begin{array}{l}\text { Non availability of labour to adopt climate } \\
\text { resilient technologies }\end{array}$ & 118 & 2.36 & III \\
\hline 4 & Non availability of critical inputs & 111 & 2.22 & IV \\
\hline 5 & High cost of inputs & 106 & 2.12 & $\mathrm{~V}$ \\
\hline 6 & Uneven and untimely rainfall & 102 & 2.04 & VI \\
\hline 7 & Power shortage & 90 & 1.80 & VII \\
\hline 8 & $\begin{array}{l}\text { Untimely release and improper scheduling of } \\
\text { water in the canals }\end{array}$ & 87 & 1.74 & VIII \\
\hline 9 & Small sized land holdings & 81 & 1.62 & IX \\
\hline 10 & Mono cropping & 72 & 1.44 & $\mathrm{X}$ \\
\hline B & Tail end $(\mathrm{N}=50)$ & & & \\
\hline 1 & $\begin{array}{l}\text { Untimely release and improper scheduling of } \\
\text { water in the canals }\end{array}$ & 136 & 2.72 & $\mathrm{I}$ \\
\hline 2 & Uneven and untimely rainfall & 130 & 2.60 & II \\
\hline 3 & $\begin{array}{l}\text { Non availability of labour to adopt climate } \\
\text { resilient technologies }\end{array}$ & 122 & 2.44 & III \\
\hline 4 & Mono cropping & 121 & 2.42 & IV \\
\hline 5 & $\begin{array}{l}\text { Lack of sufficient knowledge and guidance about } \\
\text { the climate resilient technologies }\end{array}$ & 114 & 2.28 & $\mathrm{~V}$ \\
\hline 6 & Power shortage & 108 & 2.16 & VI \\
\hline 7 & Non availability of critical inputs & 108 & 2.16 & VI \\
\hline 8 & $\begin{array}{l}\text { Limited extension activities about Climate } \\
\text { Resilient agricultural technologies }\end{array}$ & 105 & 2.10 & VII \\
\hline 9 & High cost of inputs & 92 & 1.84 & VIII \\
\hline 10 & Small sized land holdings & 83 & 1.66 & IX \\
\hline
\end{tabular}


Table.3 Suggestions of Head reach and Tail end paddy growers for greater adoption of climate resilient agricultural technologies $(n=100)$

\begin{tabular}{|c|c|c|c|c|}
\hline SI No. & Suggestions & Score & Mean score & Rank \\
\hline $\mathbf{A}$ & Head reach $(\mathbf{N}=50)$ & & & \\
\hline 1 & $\begin{array}{l}\text { Creating awareness to the farmers on scientific water } \\
\text { management }\end{array}$ & 94 & 1.88 & I \\
\hline 2 & $\begin{array}{l}\text { Involvement of local farmers in decision making in } \\
\text { releasing water to the canals }\end{array}$ & 90 & 1.80 & II \\
\hline 3 & Ensuring timely availability of inputs & 86 & 1.72 & III \\
\hline 4 & $\begin{array}{l}\text { Conducting more demonstrations and training } \\
\text { programmes on Climate Resilient Technologies in } \\
\text { paddy }\end{array}$ & 81 & 1.62 & IV \\
\hline 5 & $\begin{array}{l}\text { Conducting study tours to the successful demonstration } \\
\text { plots of farmers practising climate resilient } \\
\text { technologies }\end{array}$ & 73 & 1.46 & $\mathrm{~V}$ \\
\hline 6 & $\begin{array}{l}\text { Creating awareness to the paddy growers on } \\
\text { environmental/climate change. }\end{array}$ & 69 & 1.38 & VI \\
\hline 7 & Crop insurance at the farmers/micro level & 61 & 1.22 & VII \\
\hline 8 & Uninterrupted power supply & 58 & 1.16 & VIII \\
\hline 9 & Increasing subsidies on micro irrigation structures & 51 & 1.02 & IX \\
\hline 10 & Crop diversification & 48 & 0.96 & $X$ \\
\hline $\mathbf{A}$ & Tail end $(\mathrm{N}=50)$ & & & \\
\hline 1 & $\begin{array}{l}\text { Involvement of local farmers in decision making in } \\
\text { releasing water to the canals }\end{array}$ & 92 & 1.84 & I \\
\hline 2 & $\begin{array}{l}\text { Creating awareness to the farmers on scientific water } \\
\text { management }\end{array}$ & 89 & 1.78 & II \\
\hline 3 & Increasing subsidies on micro irrigation structures & 82 & 1.64 & III \\
\hline 4 & Crop diversification & 79 & 1.58 & IV \\
\hline 5 & Uninterrupted power supply & 75 & 1.50 & $\mathrm{~V}$ \\
\hline 6 & $\begin{array}{l}\text { Conducting more demonstrations and training } \\
\text { programmes on Climate Resilient Technologies in } \\
\text { paddy }\end{array}$ & 68 & 1.36 & VI \\
\hline 7 & $\begin{array}{l}\text { Conducting study tours to the successful demonstration } \\
\text { plots of farmers practicing climate resilient } \\
\text { technologies }\end{array}$ & 61 & 1.22 & VII \\
\hline 8 & Crop insurance at the farmers/micro level & 57 & 1.14 & VIII \\
\hline 9 & $\begin{array}{l}\text { Awareness to the paddy growers on environmental } \\
\text { changes }\end{array}$ & 53 & 1.06 & IX \\
\hline 10 & Ensuring timely availability of inputs & 46 & 0.92 & $\mathrm{X}$ \\
\hline
\end{tabular}


In the head reach area, 38 per cent of the respondents had high level economic motivation, followed by medium (34\%) and low level $(24 \%)$ economic motivation. In the tail end area, 42 per cent of the respondents had medium level economic motivation, followed by high (34 \%) and low level (24\%) economic motivation.

In the head reach area, 42 per cent of the respondents had medium level innovative proneness, followed by low (30 \%) and high level $(28 \%)$ innovative proneness. In the tail end area, 44 per cent of the respondents had high of level innovative proneness, followed by medium $(32 \%)$ and low level $(24 \%)$ innovative proneness.

In the head reach area, two fifth (40\%) of the respondents were belonged to medium level mass media exposure, followed by high (34 $\%)$ and low level (26\%) media exposure. In the tail end area, slightly more than two fifth (42\%) of the respondents were belonged to medium level mass media exposure, followed by high $(36 \%)$ and low level (22\%) mass media exposure.

In the head reach area, 38 per cent of the respondents were belonged to medium level scientific orientation, followed by low (36\%) and high level (26\%) scientific orientation. In the tail end area, two fifth $(40 \%)$ of the respondents were belonged to high level scientific orientation, followed by medium (32 \%) and low level (28\%) scientific orientation.

In the head reach area, 38 per cent of the respondents were belonged to low level extension participation, followed by medium (34\%) and high level (28\%) extension participation. In the tail end area, slightly more than two fifth (44\%) of the respondents were belonged to high level extension participation, followed by medium (34\%) and low level (22 \%) extension participation. Similar findings were reported by Arathy (2011), Jamadar (2012), Rane (2016), Sunitha (2015) Yashashwini (2016).

\section{Constraints in adoption of climate resilient} agricultural technologies as perceived by Head reach and Tail end paddy growers

In recent days, farmers are facing lot of problems in their farming; it may be climatic aberration, high input cost, low market price for their produce etc., and their situational conditions are restricting them to take up any adjustments in their farming due to climatic aberrations. With this background, efforts have been made to identify the constraints experienced by farmers in adoption of climate resilient technologies. The data in Table 2 indicates the constraints in the adoption of climate resilient agricultural technologies as expressed Head reach and Tail end paddy growers.

In the Head reach area majority of the respondents reported lack of sufficient knowledge and guidance about the climate resilient technologies (Rank I) with a mean score of 2.66 followed by limited extension activities about climate resilient agricultural technologies (Rank II) with a mean score of 2.54, non-availability of labour to adopt climate resilient technologies (Rank III) with a mean score of 2.36, non-availability of critical inputs (Rank IV) with a mean score of 2.22, high cost of inputs (Rank V) with a mean score of 2.12 , uneven and untimely rainfall (Rank VI) with a mean score of 2.04, power shortage (Rank VII) with a mean score of 1.80, untimely release and improper scheduling of water in the canals (Rank VIII) with a mean score of 1.74 , small size land holdings (Rank IX) with a mean score of 1.62 , mono cropping (Rank $\mathrm{X})$ with a mean score of 1.44 
Where as in Tail end area, majority of the respondents perceived untimely release and improper scheduling of water in the canals (Rank I) as the major constraint with mean score of 2.72. The is due to canal repair, construction work, maintenance of canals on unscientific lines and also due to low water levels in the reservoirs followed by uneven and Untimely (RANK II) rainfall as one of major constraint with mean score of 2.60 which is due to climate change which is not in the study area but also by the major parts of our state and also nation, followed by nonavailability of labour to adopt climate resilient technologies (Rank III) with a mean score of 2.44 probably because paddy cultivation involves several field operations which require more labours. I flabours were not available on time in the locality, the paddy growers had to bring labour from other neighboring villages, followed by mono cropping (Rank IV) with a mean score of 2.42 this is due paddy being the major crop in the area farmers are cultivating the paddy crop continuously crop after another crop without crop diversification which leads to loss of soil fertility and also affect their income source if the crop fails as there are no other means of income, followed by lack of sufficient knowledge and guidance about the climate resilient technologies (Rank V) with the mean score of 2.28 due to low level of education among farmers, no awareness regarding climate resilient practices and less extension activities related to it, followed by power shortage (Rank VI) with a mean score of 2.16 which may be probably due to load shedding, short circuit, followed by non-availability of critical inputs (Rank VI) with a mean score of 2.16 which is due to many inputs and equipments like drum seeder, rotary weeder, bio fertilizers, light traps are not available to the farmers locally and their supply during peak period is much less than the farmers demand, followed by limited extension activities about Climate Resilient agricultural technologies with a mean score of 2.10 which may be due to lack of demonstrations, training programmes by extension workers in the villages followed by high cost of inputs (Rank VIII) with a mean score of 1.84 which may be due to limited numbers of producers or dealers might have charged more by creating artificial scarcity followed by small sized land holdings (Rank IX) with a mean score of 1.66 which might be because of land fragmentations with the nuclear family system becoming more and increase in the population which is not economical to invest in new innovations when the per capita availability of land is limited. Findings were in line with the Tiwari (2013).

\section{Suggestions of Head reach and Tail end paddy growers for greater adoption of climate resilient agricultural technologies}

The suggestions offered by the respondents in adoption of climate resilient agricultural technologies for greater adoption in paddy cultivation are depicted in the Table 3.

In the head reach area it revealed that majority of the respondents had expressed suggestions like creating awareness to the farmers on scientific water management (Rank I) with a mean score of 1.88, involvement of local farmers in decision making in releasing water to the canals (Rank II) with a mean score of 1.80, ensuring timely availability of inputs (Rank III) with a mean score of 1.72, conducting more demonstrations and training programmes on Climate Resilient Technologies in paddy creating. (Rank IV) with a mean score of 1.62 , conducting study tours to the successful demonstration plots of farmers practising climate resilient technologies (Rank V) with a mean score of 1.46 , creating awareness to the paddy growers on environmental/climate change (Rank VI) with a mean score of 1.38 , crop insurance at the farmers/micro level 
(Rank VII) with a mean score of 1.22 , uninterrupted power supply (Rank VIII) with a mean score of 1.16, increasing subsidies on micro irrigation structures (Rank IX) with a mean score of 1.02, crop diversification (Rank X) with a mean score of 0.96 .

In the tail end area it revealed that majority of the respondents had expressed suggestions like involvement of local farmers in decision making in releasing water to the canals (Rank I) with a mean score of 1.84, creating awareness to the farmers on scientific water management (Rank II) with a mean score of 1.78, increasing subsidies on micro irrigation structures (Rank III) with a mean score of 1.64, crop diversification (Rank IV) with a mean score of 1.58, uninterrupted power supply (Rank V) with a mean score of 1.50, conducting more demonstrations and training programmes on climate resilient technologies in paddy (Rank VI) with a mean score of 1.36 , conducting study tours to the successful demonstration plots of farmers participating climate resilient technologies (Rank VII) with a mean score of 1.22, crop insurance at the farmers/micro level (Rank VIII) with a mean score of 1.14, awareness to the paddy growers on environmental changes (Rank IX) with a mean score of 1.06, ensuring timely availability of inputs (Rank $\mathrm{X}$ ) with a mean score of 0.92

So in the Head reach area the pressing need of the hour is creating awareness and educating the farmers on scientific and judicious use of water, Involving locals while making decision in release of water to the canals because irrigation department officials are releasing the water at irregular intervals which is limiting factor to the farmers to take up the climate resilient technologies. And also since majority of the farmers are not maintaining extension contact and low extension participation they are not aware of the climate resilient technologies in paddy hence there is immediate need in conducting demonstrations and training programmes on climate resilient technologies in paddy, conducting study tours to the successful demonstration plots of farmers practicing climate resilient technologies and also as this area is far away from KVK, VC Farm, Mandya they are also devoid of critical water saving equipments and also other critical inputs so extension agents and concerned officials should ensure timely availability of inputs.

Where as in the tail end area there is more need to involve local farmers while making decisions related to the timing and quantity of release of water to the canals, giving more education, training and transferring water management techniques, ensuring more subsidy on the water saving micro irrigation equipments like drip, sprinkler, drum seeder etc., and also great majority of the farmers are cultivating only paddy crop continuously which is a water intensive crop hence there is also need to educate farmers on crop diversification and encouraging them to grow different crops. Findings were in line with the Tiwari(2013).

\section{References}

Arathy, B., 2011. Constraint analysis of rice farmers of Trissur district of Kerala. M.Sc. (Ag.) Thesis. ANGRAU, Hyderabad, India.

IPCC.Managing the risks of extreme events and disasters to advance climate change adaptation summary for policymakers, special report of intergovernmental panel on climate change; 2007. (Accessed on 14th March 2015) Available:

https://www.ipcc.ch/pdf/specialreports/ srex/SREX_FD_SPM_final.pdf.

Jamadar., 2012.Farmer awareness of climate change and their adaptations. M.Sc. Thesis (Unpub), Univ. Of Agril. Sci., 
Dharwad.

Ranesatish., 2016. A study on adoption of Eco-friendly technologies among rice growers of Hanumana block of Rewa district (M.P.), M.Sc. (Agri.) Thesis (Unpub.), JNKVV.

Sunitha, A. B., 2015. Sustainability of farming systems in selected agro climatic zones of Karnataka. Ph. D. Thesis, Univ. Agri. Sci., Bangalore.

Tiwari, R. K., Jha, A., Tripathi, S. K., Khan, I. M. and Rao, S. K. 2013. Rice based cropping system and climate change. JNKVV Res J, 47, 239-247.

Venkateswarlu, B., Maheswari, M.,
SrinivasaRao, M., Rao, V.U.M., SrinivasaRao, Ch., Reddy, K.S., Ramana, D.B.V., Rama Rao, C.A., Vijay Kumar, P., Dixit, S. and Sikka, A.K. 2013.National Initiative on Climate ResilientAgriculture (NICRA), Research Highlights (2012-13). Central Research Institute for Dryland Agriculture, Hyderabad.

Yashashwini, M. A., 2016. Socio-economic impact of Hemavathi irrigation project on farmers, Ph. D. Thesis, Univ. Agri. Sci., Bangalore.

\section{How to cite this article:}

Manjunath, K. V., K. Shivaramu, Kalla Ashok and Dadimi Anilkumar Reddy. 2020. Profile Characteristics, Constraints and Suggestions of Head Reach and Tail End Paddy Growers in Adopting Climate Resilient Technologies. Int.J.Curr.Microbiol.App.Sci. 9(09): 2257-2266.

doi: https://doi.org/10.20546/ijcmas.2020.909.281 